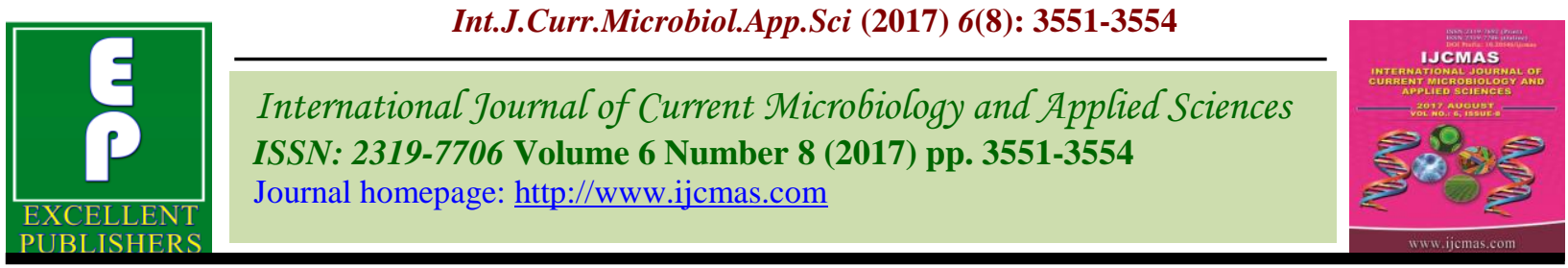

Original Research Article

https://doi.org/10.20546/ijcmas.2017.608.425

\title{
Microbial Activity in Bt Cotton Soils as Influenced by the Biofertilizer Consortia and Foliar Nutrition Under Rainfed
}

\author{
T. Laxman", T. Ramprakash, K. Avil Kumar and A. Srinivas \\ Department of Agronomy, College of Agriculture, PJTSAU, Rajendranagar, \\ Hyderabad-500 030, Telangana, India \\ *Corresponding author
}

\section{A B S T R A C T}

Keywords

Consortia, Biofertilizers, foliar application, Azotobactoer

Article Info

Accepted:

27 June 2017

Available Online:

10 August 2017
A filed experiment was conducted during rainy season of 2014 at College Farm, Professor Jayashankar Telangana State Agricultural University, Rajendranagar, Hyderabad to study the effect of biofertilizer consortia of microbes applied to soil and foliar application of macro nutrients on soil microbial activity in $\mathrm{Bt}$ Cotton. Significantly higher population of Azotobacter (4.26 $\log _{10} \mathrm{CFU} \mathrm{g}^{-1}$ soil), Pseudomonas (5.05 $\log _{10} \mathrm{CFU} \mathrm{g}^{-1}$ soil) and fungi (11.18 $\log _{10} \mathrm{CFU} \mathrm{g}^{-1}$ soil) at flowering (60 DAS) was recorded with consortia of microbes applied to soil and with foliar application of 18:18:18 @ 1.5 per cent than control (3.20, 4.03 and 7.8, log ${ }_{10} \mathrm{CFU} \mathrm{g}^{-1}$ soil, respectively).

\section{Introduction}

Cotton (Gossypium hirsutum L.) is the most important commercial crop of India cultivated in an area of 12.65 million ha with a production of 40 million bales of lint. Cotton contributes to 80 per cent of the raw material to the textile industry and provides employment to nearly 60 million people. India ranks first in area and second in global cotton production.

Actual yield levels are low due to poor agronomic practices, especially fertilization. Squaring, blooming and boll development are the stages where cotton needs the highest nutrient demand. Biofertilizers play a very significant role in improving soil fertility by fixing atmospheric nitrogen through plant roots or enhancing the availability of other trace elements such as iron, zinc, etc., and by production of plant growth-promoting regulators (Sattar and Gaur, 1987; Kucey et al., 1989; Ponmurugan and Gopi, 2006). These solubilise insoluble soil phosphates to soluble forms and produce plant growth substances in the soil. Azatobacter is a free living, non-symbiotic in nature and fixes nearly 20 to $40 \mathrm{~kg}$ nitrogen $\mathrm{ha}^{-1}$ produces growth promoting substances. Potassium solubilizing bacteria convert unavailable potassium in the soil into a form that plants can access. Simultaneous augmentation of nutrient supply through foliar application at critical stages may increase yield. Foliar nutrition when used as a supplement the crop 
gets benefitted from foliar applied nutrients when the roots are unable to meet the nutrient requirement of the crop at its critical stage (Ebelhar and Ware 1998).

Keeping in view of above points, the present investigation was carried out to find out the effect of foliar feeding and liquid biofertilizer consortia on Bt Cotton.

\section{Materials and Methods}

A field experiment was conducted at College Farm, Rajendranagar during rainy season (kharif) 2014 on a sandy clay loam soil with neutral $\mathrm{pH}$ (7.4) and low in organic carbon $(0.34 \%)$. The soil was low, medium and high in the available $\mathrm{N}\left(174.8 \mathrm{~kg} \mathrm{ha}^{-1}\right), \mathrm{P}_{2} \mathrm{O}_{5}$ (49.3kg ha $\mathrm{kg}^{-1}$ and $\mathrm{K}_{2} \mathrm{O}$ (422.4 $\mathrm{kg} \mathrm{ha}^{-1}$ ), respectively. The experiment was laid out in a randomized block design (RBD) with 10 treatments replicated thrice with a net plot area of $5.4 \mathrm{~m}$ X $3.6 \mathrm{~m}$. An intra hirsutum Bt cotton hybrid Jadhu (Boll-Gaurd II) having semi determinate plant type was used as a test cultivar.

Treatments in the experiment included $\mathrm{T}_{1^{-}}$ Control (RDF-150:60:60 N, $\mathrm{P}_{2} \mathrm{O}_{5}$ and $\mathrm{K}_{2} \mathrm{O}$ kg $\left.\mathrm{ha}^{-1}\right), \mathrm{T}_{2}$ - Consortia of microbes (PSB $+\mathrm{KSB}$ + VAM + Azotobactor) to soil @ $1 \mathrm{~L} \mathrm{ha}^{-1}, \mathrm{~T}_{3^{-}}$ Foliar application of urea @ 2 per cent, $\mathrm{T}_{4^{-}}$ Foliar application of $\mathrm{KNO}_{3} @ 2$ per cent, $\mathrm{T}_{5^{-}}$ Consortia of microbes + Foliar application of urea@2 per cent, $\mathrm{T}_{6^{-}}$Consortia of microbes + foliar application of $\mathrm{KNO}_{3}$ @ 2 per cent, $\mathrm{T}_{7}$ - Foliar application of 18:18:18@1.5 per cent, $\mathrm{T}_{8^{-}}$Foliar application of 17:44:0@2 per cent, $\mathrm{T}_{9-}$ Consortia of microbes + foliar application of 18:18:18 @ 1.5 per cent and $\mathrm{T}_{10^{-}}$Consortia of microbes + foliar application of 17:44:0 @ 2 per cent. Consortia (PSB and Azotobactor are in the form of liquid @ $250 \mathrm{ml} \mathrm{L-1}$ and KSB and VAM in the form of powder @ $250 \mathrm{~g}$ ) were mixed well and the mixture was spread uniformly on well decomposed FYM (100 kg ha $\left.{ }^{-1}\right)$ one day before application. FYM was incubated overnight by maintaining optimum moisture and applied to the soil at the time of sowing along with the seed. Foliar sprays were applied at 60, 90 and 120 DAS. Recommended dose of fertilizers and other package of practices were uniformly adopted in all the treatments for growing healthy crop.

Soil microbial activity at initial, 60 and 120 DAS was enumerated in the treatments of control $\left(\mathrm{T}_{1}\right)$ and where the consortia of microbes were applied to soil $\left(\mathrm{T}_{2}, \mathrm{~T}_{5}, \mathrm{~T}_{6}, \mathrm{~T}_{9}\right.$ and $\left.\mathrm{T}_{10}\right)$. Soil samples from rhizosphere $(0-$ $15 \mathrm{~cm})$ of these treatments were collected and brought to the laboratory in the polythene bags.

The colony forming units of Azotobactor, PSB and fungi were determined by serial dilution and plating on selective media as mentioned below. Replicates of the inoculated agar plates were incubated for 2 days at $37^{\circ} \mathrm{C}$ for bacteria, 5 days for fungi at $25^{\circ} \mathrm{C}, 7$ days for Azotobacter at $35^{\circ} \mathrm{C}$ after which the counts were taken.

The number of organisms (bacteria and fungi) per $\mathrm{kg}$ soil was calculated by applying the following formula:

Y

No. of colony

Forming units $\mathrm{kg}^{-1}$ soil = ------------ x 100

D. V

$Y=$ Average no. of colonies

$\mathrm{D}=$ Dilution factor

$\mathrm{V}=$ Volume of dilution plated

\section{Results and Discussion}

Higher soil microbial population $\left(\log { }_{10} \mathrm{CFU}\right.$ $\mathrm{g}^{-1}$ soil) viz., total beneficial microbes, Azotobacter, Psuedomonas (PSB) and fungi was recorded at flowering stage than the other stages (Table 1). 
Table.1 Microbial population ( $\log { }_{10} \mathrm{CFU} \mathrm{g}^{-1}$ soil) of rainfed Bt cotton as influenced by biofertilizer consortia and foliar nutrition

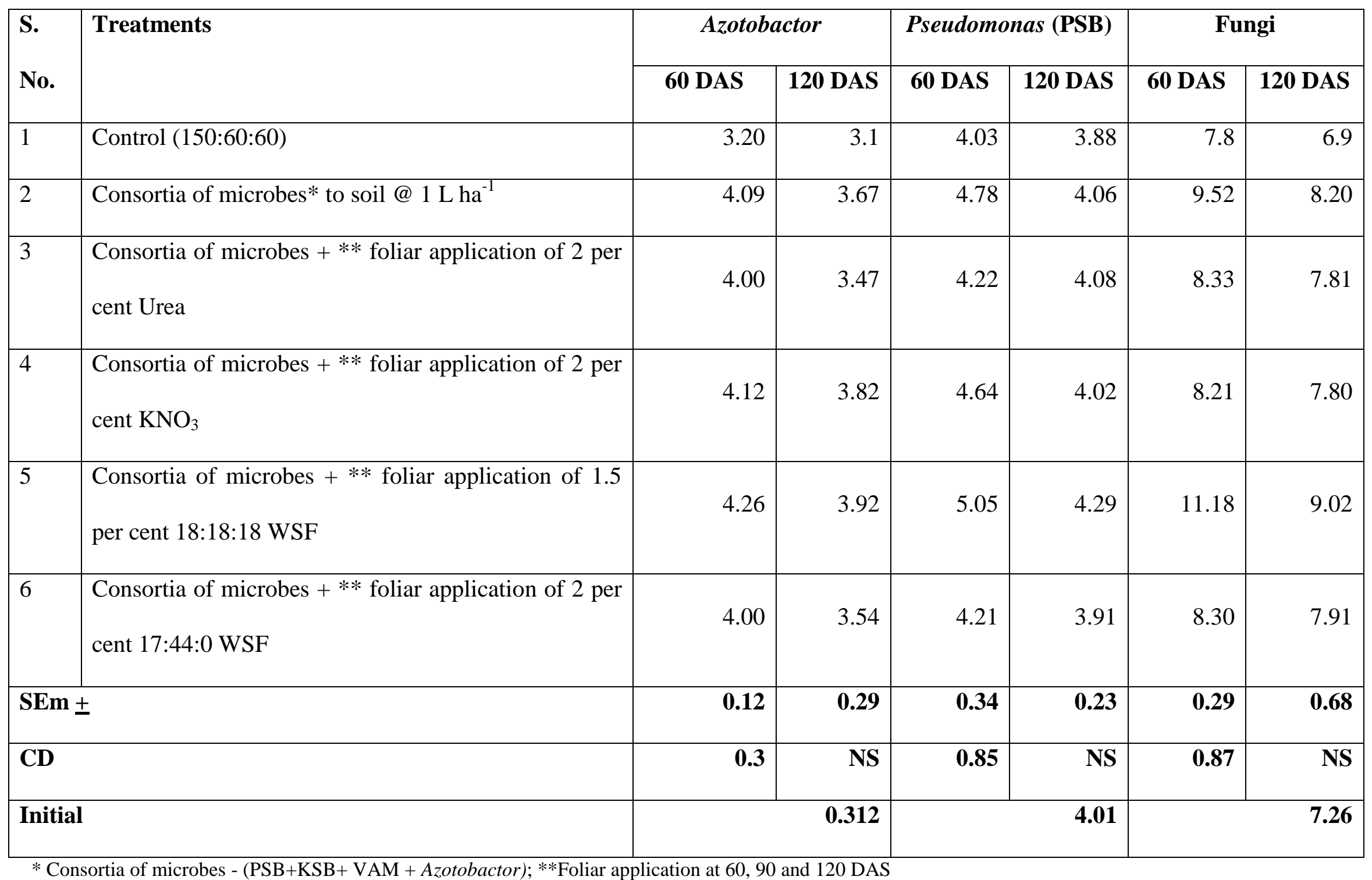


Significantly higher population of Azotobacter (4.26 $\log _{10} \mathrm{CFU} \mathrm{g}^{-1}$ soil), Pseudomonas (5.05 $\log _{10} \mathrm{CFU} \mathrm{g}{ }^{-1}$ soil) and fungi (11.18 $\log _{10} \mathrm{CFU}$ $\mathrm{g}^{-1}$ soil) at flowering (60 DAS) was recorded with consortia of microbes applied to soil with foliar application of 18:18:18@1.5 per cent and was on par with all other consortia treatments than control.

Significantly lower population of Azotobacter (3.20 $\log _{10} \mathrm{CFU} \mathrm{g}^{-1}$ soil), Pseudomonas (4.03 $\log _{10} \mathrm{CFU} \mathrm{g}{ }^{-1}$ soil) and fungi (7.8 $\log _{10} \mathrm{CFU} \mathrm{g}{ }^{-1}$ soil) was noticed in control. There was 28.1, 13.6 and 16.8 per cent mean increase of Azotobacter, pseudomonas and fungi population, respectively due to application of microbial consortia applied to soil over RDF during the flowering stage.

With increase in the crop age the microbial population at 120 DAS decreased and there is no significant difference among the treatments of consortia applied and control.

Similar types of results were reported by Audiseshamma et al., (2014) observed that bacteria and yeast populations were increased in rhizospheric soils and in case of beneficial microorganisms Rhizobium, Azospirillum and phosphate solubilizers were reduced, Azatobacter populations were increased three times in $\mathrm{Bt}$ cotton soils compared to non $\mathrm{Bt}$ cotton soils.

The population of total microbes, Azotobacter and Pseudomonas (PSB) and general fungi recorded were higher during the flowering period (60DAS) and thereafter a decreased with the increase in crop age the microbial population. Consortia of microbes applied to soil + foliar application of 18:18:18 @ 1.5 per cent recorded higher microbes of Azotobactor
(4.26 log ${ }_{10} \mathrm{CFU} \mathrm{g}^{-1}$ soil), Pseudomonas (5.05 $\log _{10} \mathrm{CFU} \mathrm{g}^{-1}$ soil) and fungi (11.18 $\log _{10} \mathrm{CFU}$ $\mathrm{g}^{-1}$ soil) than control $(3.20,4.03$ and $7.8, \log 10$ CFU $\mathrm{g}^{-1}$ soil, respectively) at 60 DAS (Flowering stage).

By this study we can conclude that soil application of biofertilizer consortia will increases the microbial population up to flowering (60DAS) and there after consortia effect will be decreased and foliar application of macro nutrient at 60, 90 and 120 DAS will not show any effect on the soil microbial population under rainfed $\mathrm{Bt}$ cotton.

\section{References}

Audiseshamma, K., Paramageetham, C.H., Charan Theja, P., Vinita Hooda and Prasada Babu. 2014. Influence of Transgenic Bt crop root exudates on rhizospheric soil microflora. International Journal of Current Microbiology and Applied Sciences. 3 (5): 289-294.

Ebelhar, M.W., and Ware, J.O. 1998. Summary of cotton yield response to foliar application of potassium nitrate and urea. Proceedings of Beltwide Cotton Conference Memphis, Tenn. 1:683-687.

Kucey, R.M.N., Janzen, H.H and Legget, M.E. 1989. Microbial mediated increases in plant available phosphorus. Advances in Agronomy. 42 : 199-228.

Ponmurugan, P., and Gopi, C. 2006. In vitro production of growth regulators and phosphatase activity by phosphate solubilizing bacteria. African Journal of Biotechnology. 5: 348-350.

Sattar, M.A., and Gaur, A.C. 1987. Production of auxins and gibberellins by phosphate dissolving microorganisms. Journal of Microbiology. 142: 393-395.

\section{How to cite this article:}

Laxman, T., T. Ramprakash, K. Avil Kumar and Srinivas, A. 2017. Microbial Activity in Bt Cotton Soils as Influenced by the Biofertilizer Consortia and Foliar Nutrition Under Rainfed. Int.J.Curr.Microbiol.App.Sci. 6(8): 3551-3554. doi: https://doi.org/10.20546/ijcmas.2017.608.425 